\title{
PENGEMBANGAN MODUL DIGITAL BAHASA INGGRIS BAGI MAHASISWA BISNIS DI ERA PANDEMI COVID-19
}

\author{
Tyas Desita Wengrum ${ }^{1}$, Adhi Nurhartanto ${ }^{2}$, \\ Universitas Mitra Indonesia, Bandar Lampung \\ Ityaswengrum@umitra.ac.id, ${ }^{2}$ nurhartanto@umitra.ac.id
}

\begin{abstract}
Abstrak: Penelitian ini merupakan penelitian pengembangan modul digital bahasa Inggris bagi mahasiswa Bisnis di era pandemic covid-19 yang sesuai dengan kebutuhan. Penelitian ini menggunakan design penelitian dan pengembangan dengan subjek uji; 2 ahli pembelajaran, 2 teman sejawat, dan 30 mahasiswa untuk validasi uji produk. Data dikumpulkan melalui kuisoner, dengan hasil penelitian: (1) skor rata-rata uji validasi oleh ahli materi sebesar 3,72 dan ahli media sebesar 4,29 dengan kualifikasi sangat baik dan beberapa revisi ringan, (2) skor rata-rata uji oleh 2 teman sejawat dosen sebesar 4,66 dengan kualifikasi sangat baik dan beebrapa revisi ringan, (3) Skor rata-rata asil validasi produk oleh 30 mahasiswa sebesar 4,41 dengan kualifikasi sangat baik. Demikian dapat disimpulkan bahwa modul digital bahasa Inggris bagi mahasiswa bisnis dikategorikan layak dan mudah digunakan.
\end{abstract}

Kata kunci: modul digital, media pembelajaran, bahasa Inggris, penelitian dan pengembangan.

Abtract: This research aims to develop an english module digital for business student during covid-19 outbreak. This research uses a research and development design with the research subjects consisting of 2 learning experts, 2 colleagues, and 30 students for product validation. The data was collected using questionnaire, with the result showed: (1) average test score by expert of content was 3,72 and by expert of media was 4,29, the qualification is very good and minor revision, (2) average test score by two colleagues was 4,66, the qualification is very good and minor revision, (3) average test by 30 students was 4,41 with very good qualification. It was concluded that English module digital for business student is categorized feasible and user friendly.

Keywords: digital module, learning media, English, research and development.

\section{PENDAHULUAN}

Bahasa Inggris merupakan bahasa terpenting utama dalam ilmu pengetahuan. Sebagai bahasa universal, Bahasa Inggris menjadi bahasa yang digunakan dalam dunia teknologi, pendidikan, politik, bisnis, dan lain sebagainya. Terlebih lagi di era globalisasi, tentunya sangat dibutuhkan kemampuan berbahasa asing, yaitu bahasa Inggris. Di Indonesia, bahasa Inggris menjadi mata pelajaran wajib di sekolah hingga perguruan tinggi. Penguaasaan bahasa Inggris sangat penting dalam berkomunikasi dan memahami teks, khususnya mahasiswa yang bukan jurusan bahasa Inggris. Oleh karena itu, untuk mencapai penguasaan bahasa Inggris bagi mahasiswa yang bukan jurusan bahasa Inggris diberikan mata kuliah bahasa Inggris bagi tujuan khusus/ English for Spesific Purpose (ESP) yang dirancang sesuai dengan disiplin ilmu setiap program studi.

Dewasa ini, pengaruh teknologi berkembang pesat dan memberikan dampak bagi setiap aspek kehidupan. Penggunaan teknologi sangat berpengaruh dan bermanfaat pada proses belajar-mengajar di kelas.
Teknologi pendidikan yang digunakan dalam pembelajaran di kelas dapat membantu mahasiswa menjadi aktif dan berinteraksi dengan baik terutama dalam situasi pandemi Covid 19 seperti sekarang. Efektivitas kegiatan belajar-mengajar ditentukan oleh perencanaan yang dilakukan oleh pendidik. Perencanaan pelaksanaan pembelajaran bukan hanya untuk melengkapi administrasi dan kurikulum, tetapi harus didesain sesuai sasaran dengan memanfaatkan perkembangan teknologi dan komunikasi. Namun, pengembangan dan penggunaan bahan ajar selama ini masih sebatas pengadaan buku cetak berupa ringkasan dan penyajian materi berupa power point. Buku cetak kurang mampu menampilkan materi melalui simulasi sehingga membuat proses pembelajaran kurang menarik dan interaktif. Bahan ajar lain berupa multimedia yang memanfaatkan teknologi informasi dan komunikasi masih sangat terbatas. Selama ini, pengembangan modul terbatas pada pengumpulan materi tanpa melakukan analisis kebutuhan. Proses pembelajaran tersebut mengakibatkan siswa tidak memahami materi secara keseluruhan dan tidak dapat berinteraksi 
dengan baik, terutama dalam perkuliahan online. Media dan teknologi diperlukan untuk diintegrasikan ke dalam mata kuliah bahasa Inggris untuk tujuan khusus/English Specific Purpose (ESP) di Perguruan Tinggi, sehingga mahasiswa dapat lebih memahami materi dan mengakses modul digital dengan mudah. Berdasarkan penjelasan di atas, dibutuhkan sebuah modul digital khususnya bagi mahasiswa yang bukan jurusan bahasa Inggris untuk mendukung proses belajar-mengajar yang efektif dan efisien baik secara tatap muka maupun daring.

Pengembangan modul digital merupakan proses merancang bahan ajar secara mandiri dan sistematis dalam bentuk digital untuk mencapai tujuan pembelajaran tertentu. Penelitian dan pengembangan (Research and Development) yang relevan dilakukan oleh Cahyani (2013) yang berjudul "Pengembangan Modul Pembelajaran Elektronika Dasar Berbasis Pendidikan Karakter di SMK Piri 1 Yogyakarta". Penelitian dari Cahyani menunjukkan bahwa modul pembelajaran elektronika sangat baik dan layak digunakan dengan hasil presentasi nilai sebesar $82.25 \%$ menurut ahli media.

Munadi (2013:98) menyatakan bahwa modul merupakan bahan ajar yang dapat digunakan oleh siswa untuk belajar secara mandiri sehingga meminimalisir bantuan dari orang lain. Selanjutnya, menurut Nasution (2013:205) modul merupakan suatu unit pembelajaran yang tersusun lengkap dan terdiri dari rangkaian kegiatan belajar yang dirancang dengan baik untuk membantu siswa mencapai tujuan pembelajaran yang sesuai. Satriawati (2015) menyatakan bahwa modul multimedia membuat proses pembelajaran menjadi lebih menarik, aktif, mampu menyampaikan pesan melalui gambar dan video, dan memberikan motivasi belajar siswa melalui instrument sehingga materi belajar mudah dipahami oleh siswa. Menurut Wahyuni (2015:4), modul merupakan salah satu media yang mampu memberikan kesempatan bagi mahasiswa untuk membangun konsep belajar mandiri yang sesuai dengan kemampuan masing-masing siswa, sehingga penggunaan modul sesuai dengan prinsip pelaksanaan kurikulum yang ada di setiap perguruan tinggi.

Berdasarkan teori di atas, dapat disimpulkan bahwa modul digital membuat proses pembelajaran lebih efektif, interaktif dan mudah diakses. Selain itu, penggunaan modul digital membuat siswa belajar mandiri sesuai dengan tingkat kebutuhan dan pengetahuan masing-masing.

Pengajaran bahasa Inggris bagi peserta didik yang bukan berlatar belakang bahasa Inggris dikenal dengan English for Specific Purposes (ESP). Sejak awal tahun 1970-an, ESP merupakan salah satu bidang ilmu linguistik terapan yang sudah dikenal dan berkembang hingga saat ini. Menurut Yaumi (2012:6) Tujuan ESP adalah supaya peserta didik mampu menguasai Bahasa Inggris sesuai pada bidang yang mereka pelajari. Misalnya mahasiswa bisnis, maka mereka harus memahami bahasa Inggris untuk bisnis. Begitu juga dengan mahasiswa kimia maka mereka harus memahami Bahasa Inggris untuk kimia, atau jika mereka mahasiswa teknik maka mereka harus mengetahui Bahasa Inggris untuk teknik dan sebagainya.

Menurut Nur (2018, p. 88), menjelaskan bahwa ESP lebih cenderung pada pembelajaran bahasa dalam konteks daripada struktur bahasa (grammar). Oleh karena itu, konteks dan penggunaan bahasa dalam situasi tertentu yang dikaitkan dengan bidang-bidang tertentu dapat membangkitkan semangat pembelajaran ESP. Selanjutnya, menurut Rusmala (2018, p. 215) peran mata kuliah bahasa Inggris sangat besar terutama ketika mahasiswa mengunakan media, alat, atau mesin dengan bahasa pengantar bahasa inggris. Selain itu, ketika mahasiswa sudah lulus kuliah dan memasuki dunia kerja, biasanya perusahaan atau industri internasional membutuhkan sumber daya manusia yang mempunyai kemampuan bahasa asing dengan baik.

Berdasarkan penjelasan di atas, disimpulkan bahwa pengajaran bahasa Inggris memiliki tujuan khusus dan disesuaikan dengan kebutuhan belajar-mengajar yang sesuai dengan jurusan masing-masing. Selain itu, penggunaan media seperti modul digital sangat berpengaruh terutama dalam pembelajaran ESP.

Terdapat beberapa tujuan penelitian di bawah ini: (1) memperoleh informasi tentang bahan ajar, (2) melakukan pengembangan media pembelajaran berupa modul digital yang sesuai dengan kebutuhan mahasiswa, (3) mengetahui kelayakan modul digital yang diusulkan. Metode penelitian ini adalah penelitian dan pengembangan dalam bidang pendidikan. Langkah-langkah utama dalam penelitian pengembangan ini, yaitu: (1) tahap analisis kebutuhan, (2) tahap pengembangan 
produk, dan (3) tahap validasi. Jenis instrument yang digunakan adalah kuisioner. Teknik analisis data yang digunakan yaitu kualitatif dan kuantitatif.

\section{METODE}

Jenis penelitian ini adalah penelitian pengembangan (research \& development) dalam bidang pendidikan. Metode Research and Development $(R \& D)$ merupakan penelitian yang digunakan untuk menghasilkan produk tertentu dan menguji keefektifan produk tersebut (Sugiyono, 2017). Model pengembangan dapat berupa model prosedural, model konseptual, dan model teoritik. Model prosedural adalah model bersifat deskriptif, yaitu menggariskan langkah-langkah yang harus diikuti untuk menghasilkan produk. Model konseptual adalah model yang bersifat analitis yang memberikan komponenkomponen produk yang akan dikembangkan serta keterkaitan antar komponen. Model teoretik adalah merupakan model yang menunjukkan hubungan perubahan antar peristiwa (Sugiyono: 2017). Dalam penelitian ini, menggunakan model pengembangan prosedural, dimana peneliti menyusun langkahlangkah untuk menghasilkan produk.

Adapun tahap pengembangan dimulai dengan: tahap analisis masalah dan kebutuhan , pengumpulan data, design produk, validasi design, revisi design, uji coba produk, revisi produk, uji coba pemakaian, revisi produk, dan produk final. Selanjutnya, prosedur pengembangan dimulai dari tahap analisis masalah dan kebutuhan meliputi, analisis validasi design sesuai kebutuhan, mengumpulkan informasi dan menetapkan tujuan, dan membuat rencana kerja. Desain penelitian ini terdiri dari desain pembelajaran dan produk. Desain pembelajaran menghasilkan RPP dan silabus, sedangkan desain produk menghasilkan isi materi modul digital dan tampilan produk. Pada tahap design produk. Subjek uji dalam penelitian pengembangan adalah 2 ahli pembelajaran, 2 dosen sejawat, dan 30 mahasiswa Fakultas Bisnis Universitas Mitra Indonesia untuk uji validasi pemakaian produk.

Selanjutnya, tahap evaluasi dilakukan pada setiap tahap pengembangan produk memperoleh produk yang sesuai dengan kebutuhan pembelajaran terutama di era pandemi Covid 19. Jenis instrument yang digunakan dalam penelitian ini adalah kuisoner.
Penilaian dilakukan oleh ahli media pembelajaran, dosen sejawat dan mahasiswa. Kuisoner berupa jawaban tertutup yang berisi komponen dengan skor 1 sampai 5 untuk setiap penilaian bagi dosen dan mahasiswa. Selanjutnya, angket untuk ahli media pembelajaran berisi deskripsi komponen media dan design. Analisis data dalam penelitian ini menggunakan kualitatif dan kuantitatif. Pendekatan kualitiatif digunakan untuk mendeskripsikan kebutuhan modul digital pada perkuliahan daring saat ini. Pendekatan kuantitatif digunakan untuk mengukur sejauh mana uji validasi pemakaian modul digital yang dihasilkan.

Hasil dari data validasi yang didapatkan dari ahli materi dan media meliputi aspek kelayakan isi, penyajian, kegrafikan dan bahasa. Data validasi teman sejawat meliputi aspek kelayakan isi, penyajian, kegrafikan dan bahasa. Penilaian aspek-aspek tersebut menggunakan skala likert seperti berikut:

Tabel 1. Skala Likert

\begin{tabular}{cc}
\hline Kriteria Nilai & Skor \\
\hline Sangat Baik & 5 \\
\hline Baik & 4 \\
\hline Sedang & 3 \\
\hline Buruk & 2 \\
\hline Sangat Buruk & 1 \\
\hline
\end{tabular}

(Sugiyono, 2016:93)

Berdasarkan hasil validasi dari 2 ahli pembelajaran (ahli materi dan media) dan 2 dosen sejawat, selanjutnya skor dihitung menggunakan jumlah total hasil masingmasing kuisoner dan dibuat rata-rata masing-masing aspek untuk mengetahui kelayakan isi, penyajian, kegrafikan, dan bahasa, serta aspek ketertatarikan, materi dan bahasa.

\section{HASIL DAN PEMBAHASAN}

Dalam penelitian ini produk yang dikembangkan berupa modul digital bahasa Inggris bagi mahasiswa bisnis. Sebelum dilakukan pengembangan modul digital bahasa Inggris bagi mahasiswa Bisnis, peneliti lebih dahulu melakukan pengumpulan informasi untuk menganalisis kebutuhan mahasiswa Fakultas Bisnis Universitas Mitra Indonesia. Pengumpulan informasi adalah langkah awal yang dilakukan dalam proses pengembangan modul digital. Penelitian dan pengumpulan 
informasi dilakukan dengan cara menyebarkan kuisoner. Berdasarkan tahapan pengumpulan infomasi ditemukan permasalahan pada proses pembelajaran saat pandemi Covid-19.

Penyampaian perkuliahan oleh dosen menggunakan sistem daring, ceramah menggunakan aplikasi zoom/google meet, dan penyampaian materi menggunakan power point mengakibatkan mahasiswa menjadi pasif dan jenuh dalam mengikuti perkuliahan, bahkan beberapa mahasiswa mengalami kendala seperti kuota, jaringan internet yang kurang memadai dan menonaktifkan video di aplikasi zoom/google meet saat perkuliahan berlangsung. Namun, pengembangan dan penggunaan bahan ajar selama ini hanya sebatas dengan pengadaan buku cetak dan power point berupa ringkasan dan penyajian materi. Penggunaan bahan ajar multimedia yang memanfaatkan teknologi informasi dan komunikasi masih sangat terbatas. Proses pembelajaran seperti ini mengakibatkan mahasiswa tidak memahami materi secara keseluruhan dan tidak dapat berinteraksi dengan baik terutama dalam perkuliahan daring. Media dan teknologi diperlukan untuk diintergrasikan ke dalam mata kuliah bahasa Inggris bagi tujuan tertentu atau English for Specific Purpose (ESP) sehingga mahasiswa lebih memahami materi dan mengakses modul dengan mudah.

Adapun tahap pengembangan dimulai dengan tahap analisis masalah dan kebutuhan, , design produk, validasi design, perbaikan design, uji coba terbatas dan tahap evaluasi. Selanjutnya, prosedur pengembangan dimulai dari tahap analisis masalah dan kebutuhan yang meliputi analisis validasi design sesuai kebutuhan, mengumpulkan informasi dan menetapkan tujuan, dan membuat rencana kerja. Selanjutnya, dilakukan pembuatan kerangka modul digital supaya terstruktur sehingga memudahkan dalam pembuatan produk/aplikasi. Penyusunan kerangka dimulai dari halaman cover, menu utama, bagian isi, daftar pustaka, rekaman materi dan glosarium. Setelah kerangka modul digital dibuat, bahan dan referensi yang telah terkumpul dipilih sesuai dengan RPS dan materi yang dibutuhkan. Produk yang dikembangkan berupa modul digital, yaitu aplikasi yang berisi materi tentang materi mata kuliah bahasa Inggris Bisnis yang disusun secara sistematis dan menarik. Pengembangan modul digital dibuat berdasarkan kebutuhan dan kondisi saat ini sehingga dapat mendukung dan mempermudah mahasiswa dalam perkuliahan daring/online.

Pengembangan berisi beberapa tahap yaitu dilakukan validasi oleh validator ahli pembelajaran menggunakan kuisoner. Validasi oleh dosen ahli materi. Validator memberikan penilaian berdasarkan aspek kelayakan serta memberikan saran dan komentar sebagai bahan revisi. Pada validasi ahli materi, penilaian terbagi menjadi dua aspek kelayakan yaitu kelayakan isi dan penyajian. Hasil penilaian ahli dihitung rata-ratanya dan dikonversikan dengan tabel konversi kualifikasi. Berikut tabel hasil validasi ahli materi:

Tabel 2. Ringkasan Hasil Validasi Ahli Materi

\begin{tabular}{llcc}
\hline No & \multicolumn{1}{c}{ Aspek } & Rata-rata & Kategori \\
\hline 1 & Kelayakan isi & 3,58 & $\begin{array}{c}\text { Sangat } \\
\text { Baik }\end{array}$ \\
\hline 2 & $\begin{array}{l}\text { Kelayakan } \\
\text { penyajian }\end{array}$ & 3,87 & $\begin{array}{c}\text { Sangat } \\
\text { Baik }\end{array}$ \\
\hline Keseluruhan & 3,72 & $\begin{array}{c}\text { Sangat } \\
\text { Baik }\end{array}$ \\
\hline
\end{tabular}

Berdasarkan hasil tabel di atas, aspek kelayakan isi dan penyajian secara keseluruhan masuk dalam kategori sangat baik. Selanjutnya, validasi ahli media. Pada validasi ahli media, penilaian terbagi menjadi dua aspek kelayakan, yaitu kelayakan kegrafikan dan bahasa. Hasil penilaian ahli juga juga dihitung hasil rata-rata dan dikonversikan dengan tabel konversi kualifikasi seperti pada hasil validasi ahli materi. Berikut tabel hasil validasi ahli media:

Tabel 3. Ringkasan Hasil Validasi Ahli Media

\begin{tabular}{llcc}
\hline No & Aspek & Rata-rata & Kategori \\
\hline 1 & $\begin{array}{l}\text { Kelayakan } \\
\text { kegrafikan }\end{array}$ & 4,14 & Sangat Baik \\
\hline 2 & $\begin{array}{l}\text { Kelayakan } \\
\text { bahasa }\end{array}$ & 4,44 & Sangat Baik \\
\hline & Keseluruhan & 4,29 & Sangat Baik \\
\hline
\end{tabular}

Berdasarkan hasil dari tabel di atas, aspek kelayakan kegrafikan dan bahasa secara keseluruhan dalam kategori sangat baik untuk digunakan. Walaupun hasil rata-rata dari kedua validator termasuk kategori valid dan sangat layak digunakan, modul digital harus tetap melewati proses perbaikan karena masih ada beberapa kesalahan dan kekurangan di beberapa bagian. Adapun revisi dari kedua ahli pembelajaran yaitu; 1) masih ada kesalahan mekanisme penulisan tata bahasa, 2) sumber 
setiap teks bacaan dan video belum dicantumkan, 3) tampilan modul digital yang masih kurang sesuai, 4) ukuran huruf sub-topik seharusnya lebih kecil dibandingkan dengan huruf topik, 5) Sebaiknya diberikan kontras warna pada tampilan menu utama.

Setelah melewati proses perbaikan, modul digital dilanjutkan ke tahap validasi oleh 2 teman sejawat. Validator memberikan penilaian.

Berdasarkan aspek kelayakan serta memberikan saran sebagai bahan perbaikan. Pada validasi teman sejawat, penilaian terbagi menjadi beberapa aspek kelayakan, yaitu kelayakan isi, penyajian, kegrafikan, dan bahasa. Hasil penilaian ahli dihitung hasil ratarata dan dikonversikan dengan tabel konversi kualifikasi seperti pada hasil validasi ahli materi dan media. Berikut tabel hasil rata-rata validasi dari 2 teman sejawat

Tabel 4. Ringkasan Hasil Validasi Teman Sejawat

\begin{tabular}{llcc}
\hline No & \multicolumn{1}{c}{ Aspek } & Rata-rata & Kategori \\
\hline 1 & Kelayakan isi & 4,78 & Sangat Baik \\
\hline 2 & $\begin{array}{l}\text { Kelayakan } \\
\text { penyajian }\end{array}$ & 4,64 & Sangat Baik \\
\hline 3 & $\begin{array}{l}\text { Kelayakan } \\
\text { kegrafikan }\end{array}$ & 4,58 & Sangat Baik \\
\hline 4 & $\begin{array}{l}\text { Kelayakan } \\
\text { Bahasa }\end{array}$ & 4,66 & Sangat Baik \\
\hline & Keseluruhan & 4,66 & Sangat Baik \\
\hline
\end{tabular}

Berdasarkan hasil tabel di atas, aspek kelayakan isi, penyajian, kegrafikan dan bahasa secara keseluruhan masuk ke kategori sangat baik untuk digunakan. Oleh karena itu, modul digital layak dan valid untuk digunakan. Terdapat beberapa saran perbaikan dari kedua validator teman sejawat yaitu; 1) Terdapat beberapa kesalahan penulisan dalam modul digital, 2) Tujuan pembelajaran di setiap awal topik perlu dijelaskan supaya memudahkan mahasiswa memahami materi, 3) Perlu ditulis semua sumber baik dari isi dan video-video pembelajaran.

Setelah melewati proses perbaikan modul digital dilanjutkan ke tahap uji validasi produk ke 30 mahasiswa. Uji validasi produk terhadap 30 mahasiswa dilakukan dengan memberikan kuisoner. Mahasiswa memberikan penilaian berdasarkan aspek ketertarikan, materi, dan bahasa. Berikut tabel hasil uji validasi oleh 30 mahasiswa:
Tabel 5. Ringkasan Hasil Validasi Mahasiswa

\begin{tabular}{llcc}
\hline No & Aspek & Rata-rata & Kategori \\
\hline 1 & Ketertarikan & 4,61 & Sangat Baik \\
\hline 2 & Materi & 4,34 & Sangat Baik \\
\hline 3 & Bahasa & 4,3 & Sangat Baik \\
\hline & Keseluruhan & 4,41 & Sangat Baik \\
\hline
\end{tabular}

Hasil uji validasi oleh 30 mahasiswa menunjukkan hasil rata-rata dari ketiga aspek yaitu aspek ketertarikan, materi dan bahasa mencapai 4,41 yang artinya modul digital layak digunakan dan meningkatkan minat mahasiswa belajar bahasa Inggris. Belawati (2003) mengatakan bahwa bahan ajar/modul berfungsi untuk memotivasi dan meningkatkan potensi yang dimiliki oleh mahasiswa. Artinya modul digital memiliki peran penting dalam kegiatan belajar-mengajar antara dosen dan mahasiswa. Berdasarkan hasil uji dari setiap aspek oleh ahli pembelajaran, teman sejawat dan mahasiswa serta saran dari masing-masing subjek uji, peneliti telah melakukan revisi yang sesuai. Selanjutnya, revisi keseluruhan terhadap pengembangan modul menghasilkan modul digital yang layak dan mudah digunakan (user friendly).

\section{PENUTUP}

Berikut kesimpulan dari penelitian yaitu:

1. Setelah melalui tahap analisis kebutuhan dan design penelitian ini menghasilkan modul digital bahasa Inggris bagi mahasiswa bisnis yang terdiri dari materi, soal dan contoh soal.

2. Berdasarkan validasi dosen ahli materi modul digital bahasa Inggris dikategorikan sangat layak digunakan dengan hasil ratarata aspek isi sebesar 3, 58 dan aspek penyajian 3,87 .

3. Berdasarkan validasi dosen ahli media modul digital bahasa Inggris dikategorikan sangat layak digunakan dengan hasil ratarata aspek kegrafikan sebesar 4,14 dan aspek bahasa 4,44 .

4. Berdasarkan validasi 2 teman sejawat modul digital bahasa Inggris dikategorikan sangat layak digunakan dengan hasil ratarata aspek isi sebesar 4,7, aspek penyajian sebesar 4,64, aspek kegrafikan sebesar 4,58 dan aspek bahasa 4,66.

5. Berdasarkan hasil uji coba produk pada 30 mahasiswa Fakultas Bisnis Universitas Mitra Indonesia dengan pengisian kuisoner, modul digital bahasa Inggris dikategorikan sangat layak digunakan 
dengan hasil rata-rata aspek ketertarikan sebesar 4,61 dan aspek materi 4,34, aspek bahasa sebesar 4,3 .

\section{DAFTAR PUSTAKA}

Belawati, Tian. (2003). Materi Pokok Pengembangan Bahan Ajar Edisi ke Satu. Jakarta: Universitas Terbuka hal1-3.

Cahyani, Dwi Agnes. (2013). Pengembangan Modul Pembelajaran Elektronika Dasar Berbasis Pendidikan Karakter di SMK Piri 1 Yogyakarta: Skripsi UNY.

Munadi, Yudhi. (2013). Media Pembelajaran (Sebuah Pendekatan Baru). Jakarta:Referensi.

Nasution. (2013). Berbagai Pendekatan dalam Proses Belajar Mengajar. Jakarta: Bumi Aksara.

Nur, M. (2018). Penerapan ESP Di Perguruan Tinggi Umum (Non English Majors) Melalui Pendekatan Content-based Instruction-cbt. Mabasan, 12(1), 86- 103.

Rusmala, M. (2018, April). Peran Mata Kuliah Bahasa Inggris dalam Pendidikan Vokasi di STKOM Sapta Computer Kalsel. Paper Presented at the Proc.Seminar Nasional Pendidikan: Peningkatan Kualitas Pendidikan Tinggi, Dasar dan Menengah.

Satriawati, Helna (2015). Pengembangan EModul Interaktif sebagai Sumber Belajar
Elektronika Dasar Kelas X SMK N 3 Yogyakarta. Thesis UNY.

Sugiyono. (2016) . Metode Penelitian Kuantitatif, Kualitatif dan R\&D. Bandung: PT Alfabet.

Sugiyono. (2017). Metode Penelitian Kuantitatif, Kualitatif, dan R\&D. Bandung: Alfabeta, CV.

Wahyuni, Sri. (2015).Pengembangan Modul Pembelajaran Fisika Berbantu Animasi Micromedia Flash Untuk Meningkatkan Hasil Belajar Mahasiswa, Jurnal Gema Pendidikan, h 4.

Yaumi, M. (2012). Pengembangan Bahan Ajar ESP Berbasis TIK. Lentera Pendidikan, 15 (2), 144-160. 